\section{The Changing Nature of Distance \\ Education in New Zealand 1992-93: Some Strategic Considerations}

\author{
Ken STEVEnS AND ORMOND TATE
}

\section{Abstract:}

Throughout 1992-1993 New Zealand educationalists have become increasingly aware of the significance of developments in information and communication technologies for teaching and learning as well as the changing nature of distance education. Increasingly, distance education methods, materials and technologies have moved into the mainstream of New Zealand education, opening new possibilities for inter-school cooperation both within this country and overseas. Recent developments in distance education open new possibilities for enhancing the provision of education and for linking schools and industry. Above all, changes in distance education over the last two years have made open learning a possibility for New Zealanders.

\section{Introduction}

$\mathrm{D}$ istance education in New Zealand has been shaped by political, educational, commercial and organisational changes, reflecting recent reforms that have taken place in the national economy and the education system, developments in communications networks and a reduction in the role of government in many aspects of public life. Over the last two years distance education has become an increasingly important strategic consideration for government, educational policy makers and the communications industry. In 1993 it is timely for distance education practitioners to reflect on the changing nature, meaning and significance of their profession.
Both the main political parties, National and Labour, considered the role of distance education in their 1993 election manifestos. The National Party noted briefly that it intended to "expand the use of technology to improve distance education" (New Zealand National Party, 1993, p. 5), while the Labour Party pointed out that it believed:

telecommunications technology has an important role in enhancing education and training [and that] a strategy for open and distance learning should be developed which is agreed upon by all parties involved and backed by the Government. (New Zealand Labour Party, p. 14)

The Labour Party's education policy included proposals for the development of an integrated communications network, funding at the samelevel open learning courses that were substantially the same as internal courses, as well as the development of specific distance education and open learning strategies for rural New Zealanders, Maori people and disabled learners. The Labour Party further noted that:

There are presently many exciting projects using new technologies, but they lack coordination at the level of government. High-tech distance learning must also be coordinated with more traditional distance education, such as the Correspondence School and the Open Polytechnic. (ibid, p. 24)

In February 1992 the Prime Minister, Mr Bolger, convened a one day conference, "Education for Enterprise", for the purpose of investigating how education could contribute to improving the country's economic position, particularly in terms of international competition.

The conference coincided with the launch of the Australian Television Open Learning Project and there was some interest expressed during the day about a similar initiative on our side of the Tasman. The Prime Minister made a commitment to the conference to explore further how telecommunications 
technologies might be put to better use for the development of interactive learning systems in a wide variety of educational and training systems... A few months later the Prime Minister's Department called for tenders to carry out a scoping study on this matter (Prebble, 1993b, p. 149).

The scoping study, known as the "Consultel Report" (Buckrell et al., 1992), noted that there was no single technological way of providing distance education that could be identified as superior. Different technologies have different applications but the report pointed out that three, in particular, were worthy of further investigation in terms of their application to the delivery of distance education: teleconferencing, broadcast television and computer mediated communications.

Teleconferencing links audio and video communications to provide a degree of interaction amongst dispersed students in the course of a lesson. It provides a sort of electronic classroom which enables all members of a geographically scattered class to participate in discussion with the teacher and with one another. Television is a medium that is widely available to New Zealanders and has the advantage of being able to be used in association with a video recorder to provide education at times convenient to the learner. Computer mediated communications enable students to interact with one another from home either privately or publicly through a class with a teacher and other students. Advantages of computer mediated communications for students include the facility to access distant data bases and libraries and transmit completed assignments to their teachers.

The Consultel report noted that the low rate of EFTS funding of distance education enrolments, when compared with face to face teaching, together with the low allocation for distance education-related capital works have made it difficult to finance the new technology needed to equip distance education institutions. This is a matter that is likely to become prominent in the development of distance education in the immediate future.
Since the publication of the Consultel Report there has been significant commercial interest in the delivery of education at a distance in New Zealand, particularly the development of the New Zealand Telelearning Network (NZTLN). The tele-learning network is a Telecom New Zealand initiative which waslaunched in late 1992. Telecom New Zealand noted that it had been developed to provide a "cost-effective application of telecommunications technology to enhanced learning". The network will have three components:

- A network of tele-learning centres, each equipped with audio, graphic, video and videoconferencing equipment. These centres may be located in tertiary and distance education institutions, primary and secondary schools, workplaces and the homes of individual students;

- A communications network to link all tele-learning centres and provide access from any telephone. The network will provide all bridging services for audio, graphics and video links;

- A network administration centre to provide a centralised reservations service for teaching institutions to gain access to remote tele-learning centres.

Telecom New Zealand's initiative promises to considerably enhance the future development of distance education in New Zealand. The company perceives its potential users to be polytechnics, universities, colleges of education and secondary schools. With emerging networks linking universities to polytechnics and polytechnics and colleges of education to secondary schools during 1993, the New Zealand Tele-learning Network is likely to play an increasingly important role in the future delivery of education to New Zealanders (Stark, 1992). In 1993 a guide to tele-learning in New Zealand was published (Swift, 1993; Tiffin et al., 1992) marking a further step in the development of this aspect of distance education.

A feature of distance education in New Zealand at present is the growing reference to open learning. Renwick (1993, p. 9) suggests that: 
The differences between open and distance education are matters for debate but both are usually defined in contrast with conventional face to face teaching. This conceptual distinction has become a settled feature of policy discourse in education.

However, in Australia in 1993, open learning has assumed new significance with the advent of the Open Learning Agency of Australia (OLAA), a Monash University led consortium of universities and polytechnics linked to $\mathrm{ABC}$ television and radio to provide courses at a distance throughout the country. At present there is no comparable institution in New Zealand.

\section{The Present Situation in New Zealand Distance Education}

Distance education in New Zealand is largely provided through four institutions: the New Zealand Correspondence School, the Open Polytechnic of New Zealand, Massey University and the Advanced Studies for Teachers Unit. In 1993 most New Zealand universities and polytechnics were developing some form of distance education to complement their conventional classrooms. Tate (1993, pp. 2-3) summed up the present state of New Zealand distance education in positive and negative terms. In positive terms he observed that:

- it is comprehensive and extends from early childhood through special and school education to the tertiary level;

- it is experienced, from many years of teaching, student support and course development;

- it has common curricula with on-campus face-to-face institutions and cross crediting of courses is possible;

- it has creditable standards and student achievement resulting in fairly general acceptance within the country.

In negative terms Tate noted that:

- there is no co-ordinating policy between institutions;

- there is poor funding and a struggle for a fair share of the education dollar;
- there is a lack of recognition in some quarters of distance education as an acceptable alternative form of education;

- there is a pervasive view that conventional classroom or oncampus is the only normal form of education and therefore superior;

- there are restrictive enrolment policies;

- there is a general omission of distance educators from policy, planning and decision making bodies;

- distance educators must operate under a system and rules made almost exclusively for conventional face-to-face education.

The Distance Education Association of New Zealand (DEANZ) represents both distance education institutions as well as individual teachers, course designers and researchers. It holds an annual conference and in 1993 considered developing a journal to provide distance education and open learning within New Zealand and the South Pacific with an international forum. Both the 1992 and 1993 conference proceedings were published (DEANZ, 1992; Rowland, 1993) and each meeting attracted both New Zealand and overseas scholars who presented papers.

The Australian and South Pacific External Studies Association (ASPESA) provides the New Zealand distance education profession with an important link to colleagues in their region. New Zealand distance educators were well-represented at the International Council for Distance Education (ICDE) conferences in Bangkok in 1992 (Scriven et al., 1993) and there are strong links being developed with the Vancouver-based Commonwealth of Learning (COL). Renwick has produced notable New Zealand contributions to key issues in international distance education over the last two years (Renwick, 1992, 1993). Renwick's current writing addresses one of the most significant and topical issues in contemporary distance education: the relationship between faceto-face teaching and distance education and the place, in this 
relationship, of new communication and information technologies. As Prebble (1993a, p. 270) notes:

Most of the distance education institutions are able to provide at least some of the features of open learning - in particular, open admission, self-paced study, alternative teaching media and flexible learning methods.

Distance education technologies, pedagogies and organisation can provide conventional educational institutions with improvements in their courses and mode of delivery. Many tertiary education institutions in New Zealand, universities and polytechnics, are today able to offer some courses by distance education and, accordingly, provide some choice in the delivery of courses to students. Prebble (1993a) points out however, that distance education in New Zealand currently lacks an explicit policy and that its development suffers accordingly.

\section{Some Strategic Implications}

During 1992-1993 there have been significant developments in distance education through political interest, commercial activity, technological change and an expansion of this aspect of New Zealand education to include non-traditional providers. Distance education and open learning have become increasingly important within the framework of the economic, educational and political life of New Zealand but the strategic implications of this have yet to be considered by the teaching profession.

Distance education is making greater use of information and communication technologies with the result that it is becoming more open to the public. While the application of these technologies to the delivery of education at a distance has the potential to improve access, openness, the scope of the curriculum and provide more immediate feedback to students, it appears that technological developments are at present well ahead of educational thinking about their effective use.
The introduction of new technologies in distance education has many implications for teachers. Technologies to link schools will make inter-institutional teaching possible. This is an attractive option for small rural classrooms with limited curricula (Stevens, 1992). However, this emerging aspect of teaching in New Zealand is not considered in pre-service teacher education programmes. The educational grounds upon which inter-school teaching should be developed and the most appropriate ways of doing so are at this stage largely unknown, even though advances in information and communication technologies makes such links possible.

The choice of the most appropriate information and communication technologies for a particular school is critical to the success of any distance education programme, but this remains a difficult and confusing area for many New Zealand educational administrators with the result that there is little coordination and little professional guidance available. As Tate (1993, p. 7) points out:

Different abilities, approaches and methods are needed to use different media and technologies effectively. Teachers find they have to learn how to prepare distance education materials for video, computer-assisted learning, telephone conferencing, etc. New instructional design methods are needed for new media and technologies. It is important that more New Zealanders become competent, preferably expert, instructional designers in new media and technologies, which have great potential.

At present distance education teachers need to learn more about new information and communication technologies so that they can capitalise on them in developing new ways of teaching and learning. A problem is that technologies are changing rapidly and there is an ongoing need for teachers to update their knowledge of them and keep developing their skills. There are five matters to be considered regarding this: a need for financial planning and co-ordination, a need for the development of data banks of educational materials, a need for the establishment and updating 
of communication networks, a need to retrain teachers and a range of issues to be considered in the teaching of students.

In the development of policy in these related areas attention will have to be given to the standardisation of both hardware and software and to the education of teachers in their classroom applications. Training in instructional design will be required if teachers are to use effectively the ever-increasing range of technology that is available. To close the gap between technological development and educational application, a coordinated approach is advocated (Tate, ibid, p. 8):

Developments on this scale can proceed faster, more economically and effectively with Government involvement as facilitators, agenda and policy setters, bringers together of conventional and distance educators, business and service people, technology specialists and potential user representatives.

The application of new information and communication technologies in education has led to the development of new learning materials. To justify the costs of developing new courses that use technology effectively, quality control is essential in the planning, development and production of distance education materials. The initial cost of developing distance learning materials is high, particularly where computer assisted learning discs and interactive $C D$ are used. Once again, to justify this cost, effective teaching and learning have to be demonstrated, there must be sufficient student numbers for courses to be viable, and such courses must be usable over long enough periods to make them economic.

The development of courses that use information and communication technologies increases open learning, open administration and open competition between institutions for students. With the development of such openness in distance education, courses are likely to become increasingly modularised with assessment designed for each module. Parallel courses of varying difficulty are likely to be developed with crossover options providing multiple learning pathways. There is likely to be increasing individualisation in course development so that particular knowledge, ability and personal requirements of students are considered. Because of the high costs of developing courses that use multiple technologies, more courses are likely to be bought from other institutions and adapted to local use. Moreover, with the development of courses under contracts, professional and commercial interests are likely to be brought together.

A critical consideration in the successful implementation of distance education has student support. Support in various forms will increasingly become a feature of the provision of education at a distance, including assistance with choice of learning options and advice on the use of such technological resources as e-mail, video and computers.

In many countries distance education has developed regionally as well as centrally, through the introduction of resource centres and the appointment of tutors with local knowledge. In New Zealand regional distance education centres provide a base from which local facilities can be arranged by staff who keep in touch with students. Local learning centres provide students with places in which they can make enquiries, discuss study problems and access computers, video players and libraries. The New Zealand Correspondence School has eleven regional representatives throughout the country from which to provide such support to students.

A major strategic consideration for distance education and open learning is the relationship between schools, universities and polytechnics with industry. Rajasingham (1992a) has emphasised the strong link between education and industry. She argues that distance education is an essential part of the relationship:

- New Zealand's sustained economic development and cultural integrity in the next decade depend on a massive expansion of education particularly at the tertiary vocational level; 
- The current education system is unable to provide the dimension of skills that will be required;

- Distance education - distance independent learning can address this need because it extends our educational environment.

Rajasingham et al. (1992b) point out how distance education can be provided at the tertiary-vocational level for those who are in employment and wish to upskill part-time through the Open Polytechnic of New Zealand. There are clear links between distance education as provided in this specialised institution, industry and the New Zealand economy.

Recent changes in New Zealand distance education have reduced physical, intellectual and professional isolation for teachers and opened up new possibilities for learners to access education regardless of location or circumstances. Perhaps distance education is now an inappropriate term to describe the networking of educational institutions and the advent of electronic teaching and learning.

\section{Conclusion}

At present there is no comprehensive distance education plan for New Zealand in spite of recent increased government and commercial interest. Prebble (1993a, p. 254) has pointed out that:

The government has withdrawn its protection of the monopolies the major institutions enjoyed over distance education. Virtually all the New Zealand universities are now involved, albeit in a small way, with distance education teaching of various kinds.

Victoria University of Wellington, one of the country's most urbanised campuses, has recently incorporated distance education within its strategic plan, although it was noted:

It is not this university's policy to become a major provider of distance education but we will develop its potential, especially in areas where we have particular national or international strengths ... links with overseas institutions (such as the presently proposed link with Heriot-Watt University in Architecture) may well lead to the franchising of distance education programmes from there together with modules derived from Victoria. (Victoria University of Wellington, 1993, p. 14)

With the proliferation of distance education providers within New Zealand, there is increased need for a co-ordinated policy to avoid duplication of expensive resources. It has been recently advocated that the Ministry of Education should:

- develop a policy to encourage potential students to avail themselves of open distance education opportunities;

- encourage distance education and open learning institutions to investigate and respond to educational requirements locally and nationally;

- establish a distance and open education advisory committee;

- establish a distance education and open learning co-ordinator who will work closely with distance educators, the proposed committee, and with other parts of the Ministry, other agencies and providing institutions to influence or develop curriculum, assessment, staffing and funding regulations and rules that are appropriate to distance education and open learning;

- foster co-operation between conventional face-to-face and distance education so that they are complementary, and not separate;

- work with the Distance Education Association of New Zealand to plan and finance research into distance education and open learning. (Tate, 1993, p. 15)

The Ministry of Education (1993) points out that by 1995 major distance education institutions will deliver distance education or open learning courses to groups previously disadvantaged by time, distance or financial resources. By 1998 distance education will be using interactive CD ROM, multi-media and videoconferencing for delivery of some courses and by 2001 an 
increasingly wide range of distance education courses will be offered to meet the needs of business, education and industry. Renwick (1993, p. 8) notes that:

The main impetus towards the use of distance education for university students has come from governments acting on the recommendations of planning agencies or advisory bodies. Open universities and dual mode universities are providing distance education because the government that funds them has requested, or directed, or permitted them to do so.

Prebble (1993a, p. 270) and Stevens (1993) point out that at present in New Zealand there is a blurring of the distinction between distance education and conventional education. Some conventional institutions now selectively use distance education materials, methods and technologies in the development of study programmes, particularly in the development of multi-site teaching. The growth of multi-site teaching within New Zealand tertiary educational institutions has a possible future international dimension (Stevens, 1993b):

A challenge for New Zealand educationalists in 1993 is the blending of distance education, open learning and conventional education to enhance the curriculum as has been commenced through the Open Learning Agency of Australia. If this challenge is not met, there may soon be an even bigger issue facing New Zealand educational administrators in this country: the extent to which New Zealand students will, in future, be taught from Australia.

Distance education in New Zealand in 1993 was in a state of change. It acquired a higher profile than it had five years ago, yet it lost some of its distinctiveness as more and more institutions sought to incorporate some distance education methods, materials and technologies into their programmes. In 1993 the major strategic consideration in distance education was the bridging of the gap between ongoing development of information and communication technologies and the implementation of appropriate pedagogies through which they might be effectively applied in New Zealand education.

\section{References}

Buckrell, P. et al., The Use of Telecommunications Technologies for the Enhancement of Educational Services, Department of the Prime Minister and Cabinet, Consultel Associates Limited, 1992.

DEANZ, Distance Education - Quality and Equity (Eighth Conference Proceedings of the Distance Education Association of New Zealand), Dunedin: DEANZ, University of Otago, 1992.

Ministry of Education, Education for the 21st Century, Wellington: Learning Media, 1993.

New Zealand Labour Party, Education - Our Children, Our Future, Wellington, 1993.

New Zealand National Party, Policy 1993 - The Most Highly Skilled Nation in the World, Wellington, 1993.

Prebble, T. "New Zealand", in Distance Education in Asia and the Pacific: Country Reports, Chiba, Japan: National Institute of MultiMedia Education, 1993a, pp. 245-273.

Prebble, T. A National Policy on Telecommunications and Open Learning: What Chance in a Deregulated Environment? Australian and South Pacific External Studies Association, 1993b.

Rajasingham, L. "ISDN and Transborder Education: The New Zealand Perspective", in Proceedings of the Ninth International Conference on Technology and Education, Vol. 2, Paris, 1992a.

Rajasingham, L., Nicoll, D. and Romiszowski, A. J. “The Technical Open Polytechnic, New Zealand", in Rumble, G. and Oliveira, J. (eds) Vocational Education at a Distance - International Perspectives, London: Kogan Page, 1992b, pp. 151-162.

Renwick, W. "Distance Education in Dual Mode Universities", in Ian Muggeridge (ed) Distance Education in Single and Dual Mode Universities, Vancouver: The Commonwealth of Learning, 1992.

Renwick, W. "The Future of Face-to-Face and Distance Teaching in PostSecondary Education", in The Impact of Information and Communication Technologies on Post-Secondary Education, Paris: CERI/OECD (in press).

Rowland, A. (ed) Distance Education - Policies, Principles and Practices, (Ninth Conference Proceedings of the Distance Education of New Zealand), Palmerston North: Massey University, DEANZ, 1993.

Scriven, B., Lundin, R. and Ryan, Y. (eds) Distance Education for the Twentyfirst Century, Brisbane: International Council for Distance 
Education and the Queensland University of Technology, 1993.

Stark, A. (ed) New Zealand Tele-learning Network, Wellington: Telecom Corporation of New Zealand, 1992.

Stevens, K. “The Potential of Distance Education Networks for Assisting Rural Students Making Vocational Choices", in Distance Education: Quality and Equity (Eighth Conference Proceedings of the Distance Education Association of New Zealand), Dunedin: DEANZ, University of Otago, 1992, pp. 135-146.

Stevens, K. "The Integration of Distance Education and the Tertiary Education Infrastructure", in New Zealand Association for Research in Education, Hamilton: University of Waikato, 1993a.

Stevens, K. "Some Implications of the Transition from Distance Education to Open Learning In Australia for the Administration of the New Zealand Curriculum", in New Zealand Journal of Educational Administration, Vol. 8 (in press).

Swift, M. Tele-Learning - A Practical Guide, Wellington: The Open Polytechnic of New Zealand, 1993.

Tate, O. A Vision of Distance Education in New Zealand, Inaugural conference of Distance Education and Information and Communications Technology Providers, Wellington: National Library of New Zealand, 1993.

Telecom New Zealand, New Zealand Tele-learning Network I Information, Wellington: Telecom Corporation of New Zealand, 1992.

Tiffin, J. W., Rajasingham, L. and Pennings, A. J. The Tele-learning Handbook, Wellington: Wordsworth Ltd, 1992.

Victoria University of Wellington, Towards Our Century - Strategic Plan 1994-1999, Wellington: Victoria University of Wellington, 1993.

\section{The authors}

Ken Stevens is a Senior Lecturer in Education at Victoria University of Wellington. His research interests are in educational administration and the sociology of education, particularly rural, distance and vocational education.

Ormond Tate is director of the New Zealand Correspondence School and an internationally recognised authority on distance education methods and policy. He was previously a senior curriculum officer with the NZ Department of Education and is a past president of the Distance Education Association of New Zealand. Recently he has been an advisory on distance education to UNESCO. 